\title{
EFFECTS OF THE REUSE OF UNTREATED WATER FROM THE AVO'O RIVER (CAMEROON) CONTAMINATED BY FECAL SLUDGE FOR THE GROWTH OF SOLANUM NIGRUM L.
}

\author{
TSAMA VN*, KOM FM, DJUYOM WV, KONE N, FONKOU T
}

Research Unit in Applied Botany, University of Dschang, Dschang, Cameroon. Email: tsama80@yahoo.fr

Received: 13 February 2021, Revised and Accepted: 21 May 2021

\section{ABSTRACT}

Objective: The main objective of this research was to evaluate the growth parameters and sanitary quality of Solanum nigrum L. irrigated with polluted water from Avo'o river in Nomayos.

Methods: Faecal sludge, water from Avo'o River and Solanum nigrum L., were analysed with respect to microbiological and parasitological parameters. Four points (S0: Control site, located in Mbankomo at $3 \mathrm{~km}$ away from faecal sludge discharge area; S1: located at $810 \mathrm{~m}$ before the faecal sludge discharge area; S2: located at $100 \mathrm{~m}$ away from the faecal sludge discharge area; and S3: located at $350 \mathrm{~m}$ after the faecal sludge discharge area) were considered for sampling events. For faecal indicator (FC: Faecal coliforms and FS: Faecal Streptococci), the membrane filtration method was used. Helminthes eggs were determined using the method of Bailenger, modified by Rodier. The growth parameters of $S$. nigrum L., measured in different site mentioned above, were plant height, number, length and width of fresh leaves.

Results: High concentration of FC (6857 \pm 5180$)$ and FS (2500 $\pm 1876 \mathrm{CFU} / 100 \mathrm{ml})$, as well as helminths eggs (273 \pm 186 eggs/L) were obtained in Avo'o water samples. The strong correlations $(\mathrm{r}=0.9)$ clearly show that the waters of the Avo'o stream influence the growth of $S$. nigrum L.

Conclusion: Despite the best growth of Solanum Nigrum L. irrigated with water from Avo'o River, high concentration of parasites was obtained on their leaves (43 eggs/100 g) highlight the necessity of a better management of faecal sludge in this city.

Keywords: Avo'o River, Fecal sludge, Growth parameters, Solanum nigrum L.

(C) 2021 The Authors. Published by Innovare Academic Sciences Pvt Ltd. This is an open access article under the CC BY license (http://creativecommons. org/licenses/by/4.0/) DOI: http://dx.doi.org/10.22159/ijags.2021v9i3.40833. Journal homepage: https://innovareacademics.in/journals/index.php/ijags

\section{INTRODUCTION}

In urban areas of many developing countries, the excreta disposal location is dramatic. Every day, all around the world, thousands of tons of sludge from onsite sanitation systems, such as traditional latrines, public toilets, and septic tanks are disposed of without previous treatment [1-3]. During the past decade, an increasing number of countries have explored the possibility of municipal wastewater and sludge reuse [4-7]. The use of wastewater for irrigation and municipal sludge utilization is becoming widely practiced not only in countries with a water deficit but also in countries with a more temperate climate. The method as well as the extent of reuse, however, varies according to the local infrastructure and the circumstances prevailing in each country. Faced with rapid population growth, cities in developing countries are subject to food insecurity and high levels of unemployment. Urban agriculture, a booming business, seems to be an additional way for the reduction of unemployment and provides food security to the city. In effect, many people have taken refuge in the production of vegetables, especially in lowlands and swamps which are floodplains with permanent moisture and richness in organic matter [7-12]. Many studies have shown the effect of wastewaters on the growth and productivity of plants in various countries of the world. Actually, the work of Mercanoglutaban and Halkman [13], Djaouda et al. [14], FAO [15], Fouepe et al. [16] focused on the evaluation of the biomass of several species of Eucalyptus camaldulensis, Acacia cyanophylus, and Populus nigra mentioned that P. nigra plants showed the greatest growth in height while Cyanophylus and Acacia manifested highest growth in diameter. Furthermore, the highest biomass was generated by A. cyanophylus, followed by Arundo donax, while biomass generation was low for Eucalyptus sp., and lowest for Populus nigra. In a recent work, the feasibility of using wastewater and sludge from secondary sewage treatments plants was studied in forest plant species of Pinus brutia (Greek origin) and Pinus maritime $[14,17,18]$. The present research work was conducted in a peri-urban area of Yaounde call Nomayos. It aimed at evaluated the effect of various treatment combinations of ordinary water and water contaminated by fecal sludge on the growth characteristics of Solanum nigrum L. The objectives were as follows: (a) To characterize different kinds of water used for irrigation of $S$. nigrum L. in the study area, (b) to evaluate the growth parameters of the plant, and (c) to evaluate the sanitary risks associated to the Solanum nigrum L. produced by farmers.

\section{METHODS}

\section{Site description}

This work was carried out along the borders of two rivers at Nomayos, a locality near Yaoundé which serves as indiscriminate dumping site of sludge collected by vacuum trucks from onsite sanitations in Yaounde (Fig. 1). The site has a surface area of about $300 \mathrm{~m}^{2}$ and receives approximately $1350 \mathrm{~m}^{3}$ of untreated fecal sludge per week.

\section{Methodology}

Samples of faecal sludge, water from Avo'o River and S. nigrum L., were analyzed with respect to microbiological and parasitological parameters. For this, 4 points (S0: Control site, located in Mbankomo $3 \mathrm{~km}$ away from faecal sludge discharge area; S1: Site one located at $810 \mathrm{~m}$ before the faecal sludge discharge area; S2: Site 2 located $100 \mathrm{~m}$ away from the faecal sludge discharge area; and S3: Site 3 located $350 \mathrm{~m}$ after the faecal sludge discharge area) were considered for sampling events. Looking microbiological analyses, fecal streptococci and fecal coliforms were determined in each sample using the membrane filtration protocol described by Rodier [19], WHO [20] for parasitological analysis, helminthes eggs were determined using the 


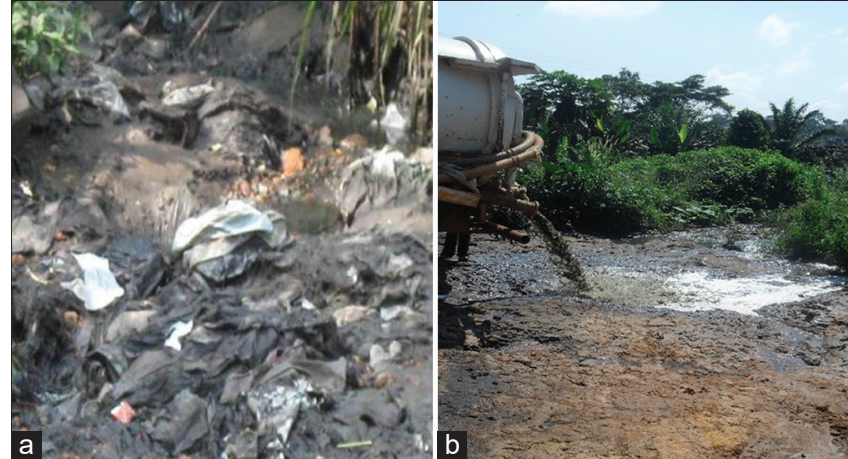

Fig. 1: Site of study: (a) depositing of fecal sludge, (b) wastes on the site

method described by Bailenger and modified by Rodier [19], WHO [20]. The growth parameters of S. nigrum L., monthly measured in different site mentioned above were evaluated and considered parameters were plant height, number, and length and width of fresh leaves. Plant height was measured using a double decameter; number of fresh leaves and number of the dead plant determined by counting; length of leaves, measured with a caliper.

\section{Data analysis}

The ANOVA test was conducted to reveal the effects of different treatments applied on the bacteriological, parasitological, and morphological parameters of S. nigrum L. using SPSS software.

\section{RESULTS AND DISCUSSION}

Analyses of sludge, waters of Avo'o River, and lettuce plants from the studied sites revealed the presence of indicators of fecal pollution: Fecal coliforms and fecal streptococci (Table 1). Mean values of these bacterial indicators in fecal sludge are $22.86 \times 10^{5} \mathrm{CFU} / 100$ $\mathrm{ml}$ and $10.68 \times 10^{5} \mathrm{CFU} / 100 \mathrm{ml}$, respectively, for fecal coliforms and streptococci. These mean values are 1400 and $370 \mathrm{CFU} / 100 \mathrm{ml}, 3200$ and $1480 \mathrm{CFU} / 100 \mathrm{ml}, 4580$ and $1540 \mathrm{CFU} / 100 \mathrm{ml}, 1112$ and 264, 20 $\mathrm{CFU} / 100 \mathrm{ml}$, and 3888 and $1448 \mathrm{CFU} / 100 \mathrm{ml}$, respectively, for sites S1, S2, S3, S0, and S. nigrum L. plant. A very strong linear correlation with Pearson's test was observed between the levels of indicators of fecal pollution in the sludge, the waters points of river Avo'o, and leaves of S. nigrum L.

\section{Microbiological characteristics of water use}

The most important feature of this work is the very high values of pathogens in sludge, revealing the highly polluted nature of the raw sludge drain. Similar results were obtained by FAO [15], Esaw and Mohamed [21], Kengne [22] working on the factors affecting the dewatering of fecal sludge using constructed wetlands in tropical region. The bacteriological characteristics of Avo'o River waters contaminated by drains from the Nomayos sludge discharge area reveal pollution levels that are highly above the standards restrictive values recommended for irrigation waters used in the cultivation of edible crops $(<1000 \mathrm{CFU}$ for fecal bacteria and 1 helminth ova/100 $\mathrm{g}$ of S. nigrum L. of edible crops) [20]. These values reflect the importance of sludge on the environmental pollution. Similar observations were made by Bea et al. [11], Mercanoglutaban and Halkman [13], Kengne et al. [22] who noted that the uncontrolled discharge of excreta in the environment does not respect the principles of ecological and health care, especially in developing countries. In addition, these authors described the transmission routes of disease: Direct contact with feces during swimming and the consumption of food and water dysentery, malaria, etc., affect as many as $53 \%$ of urban dwellers both in Douala and contaminated by pathogenic germs. For these authors, the wastewater contaminated with excreta can be used in agriculture. However, care must take to avoid contamination for municipal sludge and wastewaters generally contain four major kinds of pathogens [6]:
Table 1: Microbiological characteristics of samples ( $n=33$ for each sample)

\begin{tabular}{lll}
\hline Sample & CF (UFC/100 ml) & SF (UFC/100 ml) \\
\hline Fecal sludge & $22.86 \times 10^{5} \pm 25.47 \times 10^{2}$ & $10.68 \times 10^{5} \pm 16.46 \times 10^{2}$ \\
S0 & $1112.00 \pm 1013.25$ & $264.20 \pm 189.52$ \\
S1 & $1400.00 \pm 1160.44$ & $370.00 \pm 132.06$ \\
S2 & $3200.00 \pm 2280.77$ & $1480.00 \pm 1200.00$ \\
S3 & $4580.00 \pm 2902.06$ & $1540.00 \pm 1420.56$ \\
Solanum nigrum L. & $349.41 \pm 119.85$ & $153 \pm 114.68$ \\
(UFC $/ 100$ g) & &
\end{tabular}
(UFC/100 g)

S0: Control, S1: Before discharge, S2: Discharge area, S3: After discharge area

Bacteria, protozoa, viruses, and helminths eggs. This contamination of $S$. nigrum L. is accentuated by the irrigation method; sprinkling irrigation significantly increases the risk of contamination. However, most farmers use wastewater to irrigate their crops by spraying with watering cans. It has been applied to establish the health risks associated with consuming wastewater-irrigated food crops and also applied quantitative microbial risk assessment for the evaluation of health risks for farmers using wastewater under different irrigation regimes and technologies [18,22-24] and vegetables [6,21,25-27]. The use of these plants for food supply without respect of hygiene can be associated to waterborne diseases. Outbreaks of waterborne diseases (diarrhea, cholera, typhoid fever, dysentery, malaria, etc.) affect as many as $53 \%$ of urban dwellers both in Douala and Yaounde. Others such as typhoid fever and diarrhea represent, respectively, $32 \%$ and $43 \%$ of waterborne diseases that affect the population of Cameroon [22].

\section{Parasitological characteristics}

There have been approbation numbers of risk factors for the reuse of wastewater for agricultural irrigation. Some risk factors are short term and vary in severity depending on the potential for human, animal, or microbial pathogens to have contact with the environment [28]. It is worth recalling that the most common human microbial pathogens found in wastewater are of enteric origin. This uncontrolled use of wastewater in agriculture has significant health implications for product consumers, farmers and their families, vendors, and producer communities in wastewater irrigated areas [1].

A total of 3601 helminths eggs/L of fecal sludge, 285 helminths ova/L of irrigated water, and 43 helminths eggs/100 g of S. nigrum L. were obtained. These parasite concentrations show that fecal sludge his high pollutant with influence on the parasitological characteristics of Avo'o River water and lettuce. Looking to these concentrations, sludge analyzed can be range in category. A sludge type according to the classification of Strauss et al. [12] because the concentrations of helminth eggs are similar to those obtained by these authors. The characteristics of samples exhibit a great disadvantage of wastewater reuse due to its effect on public health.

Regarding the types of parasites observed in the samples, parasite species recorded at different sampling points are Ascaris lumbricoides, Enterobius sp., Trichuris trichiura, Taenia sp., and Schistosoma sp. Heterogeneity was observed in the type and number of parasite species recorded at the sampling sites. S0 sample site has registered only two parasite species which are A. lumbricoides (28.33 eggs/L) and T. trichiura (3.33 eggs/L). Globally, A. lumbricoides was the most represented species with a frequency of $84.16 \%$. Sites S0 and sample of wastewater of Avo'o River allowed the registration of five species of parasites A. lumbricoides, Enterobius sp., Hookworm sp., T. trichiura sp., and Schistosoma sp. Average numbers of eggs per liter samples are $540 ; 123 ; 33 ; 141 ; 66 ; 62 ; 25 ; 13$; and 26 , respectively, for each parasite. The presence of parasites in the river water can be explained by its proximity to indiscriminate sludge discharge site. This has a direct influence on the quality of water resources of the site (Table 2). 
Table 2: Mean number of helminth eggs in different samples $n=33$ for each sample

\begin{tabular}{llll}
\hline Mean \pm Standard deviation (eggs/L) & & \\
\hline Parasites & S0 & S1 & S2 \\
\hline Ascaris L. & $28.33 \pm 10.30$ & $143.33 \pm 51.13$ & $168.33 \pm 62$ \\
Enterobius sp. & 0 & $28.33 \pm 10.29$ & $45 \pm 24.30$ \\
Ancylostoma sp. & 0 & $37.50 \pm 24.16$ & $36.67 \pm 26.40$ \\
Trichuris trichiura & $3.33 \pm 11.5$ & $2.50 \pm 8.66$ & $24.75 \pm 23.65$ \\
Taenia sp. & 0 & 0 & 0 \\
Schistosoma & 0 & $2.1 \pm 1.85$ & $4.5 \pm 1.66$ \\
Entamoeba histolytica & 0 & $42.5 \pm 49.33$ & $71.17 \pm 51$ \\
Entamoeba coli & $1 \pm 3.40$ & $3.33 \pm 7.84$ & $26.67 \pm 35.00$ \\
Total & $32.66 \pm 24.75$ & $237.20 \pm 140.33$ & $35 \pm 32.05$ \\
\hline
\end{tabular}

Table 3: Matrix of correlation between different growth parameters of Solanum nigrum L.

\begin{tabular}{lllllll}
\hline & $\begin{array}{l}\text { Dead of } \\
\text { plant }\end{array}$ & height & $\begin{array}{l}\text { Fresh } \\
\text { leaves }\end{array}$ & $\begin{array}{l}\text { Dry } \\
\text { leaves }\end{array}$ & $\begin{array}{l}\text { Length } \\
\text { of leaves }\end{array}$ & $\begin{array}{l}\text { Width of } \\
\text { leaves }\end{array}$ \\
\hline $\begin{array}{l}\text { Dead } \\
\text { plant }\end{array}$ & 1 & -0.516 & -0.801 & 0.792 & 0.965 & 0.882 \\
$\begin{array}{l}\text { Height } \\
\text { Fresh } \\
\text { leaves }\end{array}$ & -0.516 & 1 & 0.925 & 0.103 & -0.278 & -0.062 \\
$\begin{array}{l}\text { Dry } \\
\text { leaves }\end{array}$ & 0.792 & 0.103 & -0.275 & 1 & 0.913 & 0.984 \\
$\begin{array}{l}\text { Length of } \\
\text { leaves }\end{array}$ & 0.965 & -0.278 & -0.621 & 0.913 & 1 & 0.965 \\
\hline
\end{tabular}

\section{Evolution of growth parameters}

Plant growth is expressed in terms the number of fresh leaves, height of plant, and leaves leaf area increased with time irrespective of the different treatments studied (Fig. 2). There is a significant difference $(p<0.001)$ with Student's test in plant fresh leaves, height of plant, and length of leaf and width of leaves between treatments. After 9 weeks of operation, an increase of parameters proportional to treatments was noted for the treatment (S0-S3). The use of wastewater resulted in greater number of plant leaves, plant height, and leaves areas. On the number of fresh leaves, treatment 3 (S3) located after the fecal sludge discharge site showed the largest number of leaves with an average of 34.63 leaves in the $9^{\text {th }}$ week for site 1 and 40.33 leaves for site 2 . A gradual increase in the height of plants was also observed as a function of time and the treatments studied for all investigation sites. The mean values obtained in the $9^{\text {th }}$ week were $11.5 \mathrm{~cm}^{2}$ and $13.99 \mathrm{~cm}^{2}$ for treatment $S 3$ on sites 1 and 2 , respectively. Site 2 yielded plants with largest leaf surfaces. From the $1^{\text {st }}$ to the $5^{\text {th }}$ week of growth, evolution was similarly independent of sites and treatments used. The rapid increase of these parameters could be justified by the presence of excessive nutrients bring by fecal sludge, all of which are mineralized and rendered bioavailable by bacteria present in the soil [29]. These results corroborate with those obtained by Tripathi et al. [30] which showed that there exists a relationship between increase in nutrient concentration in wastewater and absorption by plants for growth. Similar observations were made by Kalavrouziotis et al. [18] working on the assessment of sewage effluent quality from sewage treatment plant.

\section{Analyses of correlation between different growth parameters}

Correlation matrix between growth parameters of $S$. nigrum L. shows that:

- There is a strong correlation between fresh leaves and height of S. nigrum L. with $\mathrm{r}=0.9$

- $\quad$ There is a strong correlation between dead of plant, length and width of fresh leaves with $\mathrm{r}=0.9$

- $\quad$ Strong correlation between dead plants and dry leaves with $r=0.7$

- There is a negative correlation between height and width of fresh leaves with $\mathrm{r}=-0.278$ and $\mathrm{r}=-0.062$

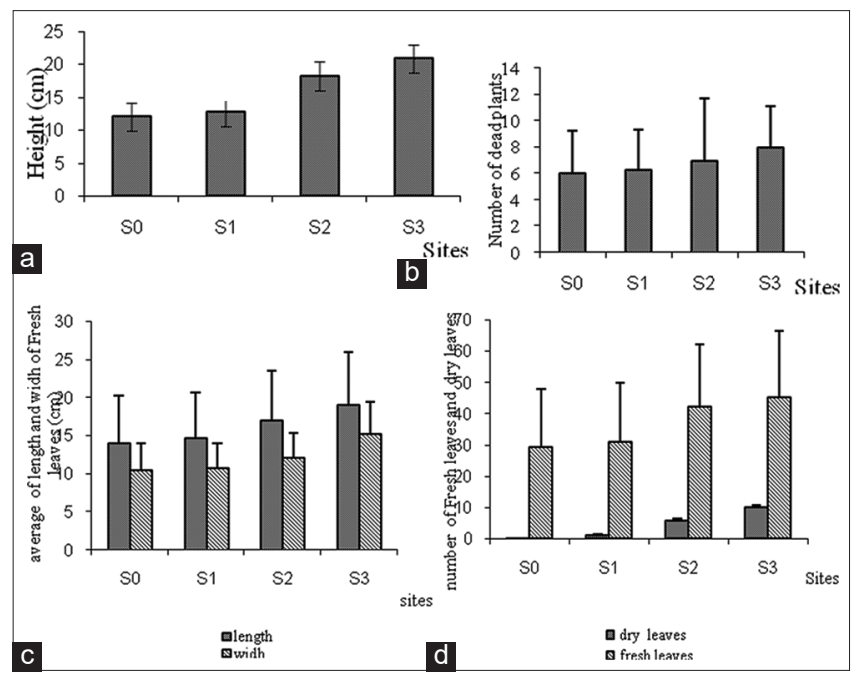

Fig. 2: Evolution of growth parameters of Solanum nigrum L.

(a) Height of plant, (b) average number of dead plants, (c) average of length and width of fresh leaves, (d) average number of fresh leaves and dry leaves

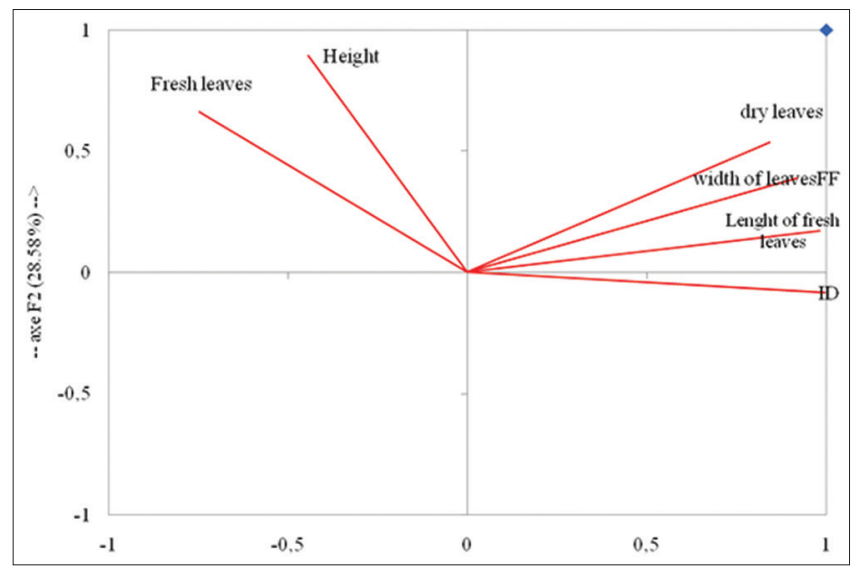

Fig. 3: Median component analysis of growth parameters of Solanum nigrum $\mathrm{L}$.

- $\quad$ There is a negative correlation between number of dry leaves and number of fresh leaves with $\mathrm{r}=-0.275$

- Strong correlation between number of dead plants and dry leaves with $\mathrm{r}=0.84$

- Absence of correlation between height and dry leaves of $S$. nigrum L. with $r=0.10$.

These strong correlations clearly show that the waters of the Avo'o stream influence the growth of $S$. nigrum plants. The number of fresh 
leaves increases with width of plants $(r=0.9)$. The number of fresh leaves increases with height of plants $(r=0.9)$ and the number of dead plants is influenced by the number of dry leaves ( $r=0.84)$ (Table 3 ).

The PCA confirms the results of the analysis of variance which shows that sites and seasons have a highly significant effect on the parameters at the threshold $\mathrm{p}<0.001$ (Fig. 3). There is, therefore, a link between the waters of Avo'o stream contaminated by the fecal sludge dump and the growth of $S$. nigrum L.

\section{CONCLUSION}

The reuse of wastewater contaminated by fecal sludge for irrigation of crops can be associated to infectious diseases caused by pathogenic microorganisms because the majority of pathogens that affect humans are derived from feces and transmitted by the fecal or oral route. Despite the noticeable growth of $S$. nigrum L., high concentrations of fecal coliforms, fecal streptococci, and parasites were identified on their leaves. The necessity to better manage fecal sludge in this city is required for social and environmental health safety.

\section{REFERENCES}

1. Carr R. Who guidelines for safe wastewater use-more than just numbers J Irrig Drainage 2011;54:103-111.

2. Delville PL, Boucher L. Les Bas-fonds en Afrique Tropicale Humide. Guide de Diagnostic et D'intervention. Paris : Collection Le point sur Gret Ministère de la Coopération CTA; 2006. p. 37-68.

3. Ingallinella AM, Sanguinetti TK, Montangero A, Strauss M. The challenge of faecal sludge management in urban areas-strategies regulations and treatment options. Water Sci Technol 2002;46:285-94.

4. Mara D, Cairncross S. Guide Lines for the Safe Use of Wastewater and Excreta in Agriculture and Aquaculture. Geneva, Switzerland: World Health Organization; 1999. p. 1-20.

5. Hass CN, Rose JB, Gerba CP. Quantitative Microbial Risk Assessment. New York: Willey; 1999. p. 23.

6. Mara D, Sleigh PA, Blumenthal UJ, Carr RM. Health risks in wastewater irrigation: comparing estimates from quantitative epidemiological studies. J Water Health 2007:5:39-50.

7. Mbaye A, Moustier P. Market-oriented urban agricultural production in Dakar. In: Bukker N, editor. Growing Cities, Growing Food. Feldafing, Germany: DSE; 2000. p. 235-56.

8. Allende A, Monaghan J. Irrigation water quality for leafy crops: A perspective of risks and potential solution. Int J Environ Re 2015;42:79-87.

9. Allende A, Tondo EC. Microbial quality of irrigation water used in leafy green production in Southern Brasil and its relationship with produce safety. Food Microbiol 2017;65:105-13.

10. Assongmo T. L'occupation et L'aménagement des Bas-fonds à Yaoundé: Le cas du Bassin Versant d'Olézoa. Yaoundé: Mémoire de Maîtrise, Université de Yaoundé; 1990. p. 172.

11. Bea CB, Angela MZ, Dimasupil PG, Kenneth V, Widmer W, Winndell LR. Faecal contamination in irrigation water and microbial quality of vegetable primary production in urban farms of metro Manila, Phillipine. J Environ Sci 2015;50:734-43.

12. Strauss M, Larmie SA, Heinss U. Treatment of sludge from onsite sanitation: Low-cost options. Water Sci Technol 1997;35:129-13.

13. Mercanoglutaban B, Halkman AK. Do leafy green vegetables and their ready to eat salads carry a risk of food borne pathogens? Anaerobe 2011;17:286-7.

14. Djaouda M, Nola M, Gake B, Ebang MD, Djine T. Faecal contamination of well water in Garoua (Cameroon). Importance of household storage and sanitary hygiene. Int J Res Chem Environ 2011;11:97-103.

15. Food and Agriculture Organization. Water Pollution from Agriculture: A Global Review. Food and Agriculture Organization of the United Nation and the International Water Management Institute on Behalf of the Water Land and Ecosystems Research Program Colombo. United Nations: Food and Agriculture Organization; 2017. p. 34.

16. Fouepe TA, Kuitcha D, Sigha L, Ntonga JC. Impact de la Vulnérabilité des Ressources en Eau de Surface sur L'accès à l'eau Potable des Populations de la Ville de Yaoundé: Stratégies D'adaptation. Présentation 6eme Édition Journée Entreprise 2IE, Ouagadougou; 2011. p. 4.

17. Djuikom E, Jugnia LB, Nola M, Foto S, Sikati V. Physicochemica water quality of the Mfoundi River watershed at Yaounde Cameroon and its relevance to the distribution of bacterial indicators of faecal contamination. Water Sci Technol 2009;60:2841-9

18. Kalavrouziotis IK, Koukoulakis PH, Sakelariou-Makrantonaki M, Papanikolaou C. Effects of treated municipal wastewater on the essential nutrient interactions in the plant of Brassica oleracea var italica. Desalination 2009;242:297-312.

19. Rodier J. L'analyse de l'eau; Eau naturelle, eau Résiduaire, eau de Mer. 9é édition. Paris: Dunod Technique; 2009.p. 709-85.

20. World Health Organization. World Health Report 2004: Changing History. Burden of Disease in Dalys by Cause, Sex and Mortality Stratum in WHO Regions. Geneva: World Health Organization; 2002. Available from: http://www.who.int/whr/2004/en. [Last accessed on 2020 Jan 27].

21. Esaw KM, Mohamed AG. Effect of polluted water on soil and plant contamination by heavy metals in El Mahla El-Kobra, Egypt. Solid Earth 2016;3:703-11.

22. Kengne IM. Potentials of Sludge Drying Beds Vegetated with Cyperus papyrus L. and Echinochloa pyramidalis (Lam.) Hitchc and Chase for Faecal Sludge Treatment in Tropical Region. Doctorat/Ph.D Thesis in Plant Biology, Specialty: Phytoremediation; 2008a. p. 114.

23. Jimenez B, Takasshi A. Water reclamation and reuse around the world In: Jimenez B, Takashi A, editors. Water Reuse: An International Survey of Current Practice, Issues and Needs. London, United Kingdom: IWA Publishing; 2008. p. 3-26.

24. Kengne IM. Profil environnemental du Cameroun: Rapport Provisoire; 2008b. p. 140.

25. Niyitegeka D. Bioindicateurs et Pathogènes Bactériens des Eaux du Mingoa et du Lac Municipal de Yaoundé: Conditions du Milieu, Structure des Peuplements, Répartition Spatiale et Fluctuation Temporelles. Cameroon: Doctorate Dissertation, University of Yaounde I; 2001. p. 254.

26. Petterson SR, Ashbolt N, Sharma A. Microbial risks from wastewate irrigation of salad crops: A screening-level risk assessment. Water Environ Res 2001;72:667-72.

27. Shuval H, Lampert Y, Fattal B. Development of a risk assessment approach for evaluating wastewater reuse standards for agriculture. Water Sci Technol 1997;35:15-20.

28. Gibson LL, Rose JB, Hass CN. Use of quantitative microbial risk assessment for evaluation of the benefits of laundry sanitation. Am J Inf Control 1999;99:70040-4

29. Vymazal J. Types of constructed wetlands for wastewater treatment: Their potential for nutrient removal. In: Transformation of Nutrients in Natural and Constructed Wetlands. Leiden, The Netherlands: Backuys Publishers; 2001. p. 1-93.

30. Tripathi BD, Srivastava J, Misra K. Nitrogen and phosphorus removal capacity of four chosen aquatic macrophytes in tropical freshwater ponds. Environ Cons 1991;18:143-7. 